\title{
Microencapsulated Eucalyptol and Eugenol as Growth Promoters in Broilers
}

\author{
Rodrigo Scherer ${ }^{*}$, Stanislau Bogusz Junior ${ }^{2}$, Ricardo de Albuquerque $^{3}$, Helena Teixeira Godoy ${ }^{4}$ \\ ${ }^{1}$ Universidade Vila Velha (UVV), Faculdade de Farmácia. Vila Velha, ES, Brasil.; \\ ${ }^{2}$ Universidade Federal dos Vales do Jequitinhonha e Mucuri (UFVJM), Instituto de Ciência e Tecnologia (ICT), \\ Diamantina, MG, Brasil; \\ ${ }^{3}$ Universidade de São Paulo (USP), Faculdade de Medicina Veterinária e Zootecnia, Pirassununga, SP, Brasil; \\ ${ }^{4}$ Universidade Estadual de Campinas (UNICAMP), Faculdade de Engenharia de Alimentos, Campinas, SP, Brasil. \\ * rodrigo.scherer@uvv.br
}

\begin{abstract}
Antibiotic growth promoter has been effectively used in poultry production for stimulating growth and preventing diseases. However, the use of antibiotics has been questioned due to the possible appearance of resistant bacteria. Special attention has been paid to the use of essential oils as natural alternatives for antibiotics. We investigated the use of different concentrations of spray dryer microencapsulated eucalyptol and eugenol in broiler chickens diet as alternative growth promoters for avilamycin. One-day-old male broiler chickens were submitted to 7 different dietary treatments. The eugenol demonstrated strong antioxidant activity and both eugenol and eucalyptol showed antimicrobial activity. The broiler performance showed no significant difference to the group with administration of $10 \mathrm{mg} / \mathrm{kg}$ of avilamycin when eucalyptol $(500 \mathrm{mg} / \mathrm{kg})$ or eugenol $(500 \mathrm{mg} / \mathrm{kg})$ were used separately in diet. Our findings suggest that the microencapsulated phytotherapic agents are a potential alternative to the use of avilamycin as growth promoter in broilers during the broilers growing phase.
\end{abstract}

Keywords: antibiotic alternative, antimicrobial activity, antioxidant activity, phytotherapic agents.

Recebido: 25 Setembro de 2014; aceito: 14 de novembro de 2014, publicado: 18 de Novembro de 2014.

DOI: $10.14685 /$ rebrapa.v5i1.157

\section{INTRODUCTION}

Antibiotic growth promoter has been effectively used in poultry feed for stimulating growth, treating sickness and preventing disease among the animals (KHAKSAR et al., 2012). However, the increasing concern over food safety leads to an apprehension over the use of antibiotics (ROSEN, 1996; CASEWELL et al., 2003; PHILLIPS et al., 2004). The major risk consists in the indiscriminate use of antibiotics and the consequent spread of resistant bacteria which can be harmful to human health due to the difficulty of clinical treatment (PHILLIPS et al., 2004; CASTANON, 2007).

In 2006, the European Union (EU) approved a resolution that removal the antibiotic growth promoter for animal feed (CROSS et al., 2007). Ever since, many countries around the world made efforts to finding substitutes for antibiotic growth promoters in poultry feed (CASEWELL et al., 2003; PHILLIPS et al., 2004;
CASTANON, 2007). Alternatives are being introduced and special attention has been paid to the use of natural compounds, especially essential oils, as natural alternatives for antibiotics (CROSS et al., 2007; KHODAMBAS, et al., 2012). Many natural compounds used as substitutes for antibiotics in animal feed demonstrated positive effects on growth performance and in different health parameters (AGUILAR et al., 2013, JAMROZ et al., 2006, WINDISCH et al., 2008 ).

Essential oil from plant extracts has distinct biological functions, such as antimicrobial, antifungal or antioxidant activities (LEE and AHN, 1998). The supplementation of poultry diets with essential oil has favorable effects in digestive enzymes (LEE et al., 2003; JANG et $a l ., 2004)$ and in the intestinal microflora since they inhibit harmful microbial growth in the gut and increase the digestibility (HELANDER et al., 1998). The essential oils have numerous 
advantages over commercial antibiotics since they are residue free and they are also usually used in the food industry (VAREL, 2002; BRENES and ROURA, 2010). Eugenol and eucalyptol, the major chemical component of clove and eucalyptus oil, respectively, act as antioxidants on oleaginous foods, antiseptics in pharmacology, anti-inflammatories and as antimicrobial agents (FARAG et al., 1989; SAN MYINFF et al., 1996). Therefore, they are potential substitutes for antibiotic growth promoters.

The microencapsulation provides an important tool for the industry, enabling the protection and controlled release of various active agents. Microcapsules are small particles with a size between 1 and 1000 um comprising an active agent surrounded by a natural or synthetic polymeric membrane. The encapsulation of essential oils in core-shell has been used for several reasons, for example, protection against oxidative decomposition and evaporation, odor masking or merely to act as a support for ensuring control of the dose to be administered (MARTINS, et al., 2014).

In this article, we investigated the use of different levels of microencapsulated eucalyptol and eugenol in broiler chickens diet as alternative growth promoters for commercial antibiotic avilamycin.

\section{MATERIALS AND METHODS}

\section{Birds and Diet}

A total of 392 male, one-day-old male broiler chicks (Ross) were housed in metal cages with $100 \mathrm{~W}$ lamps for heating, trough feeders and nipple-type water supply. There were seven dietary treatments; each treatment consisted of 8 repetitions and 7 chicks per experimental unit. The birds were randomly assigned to the corresponding experimental diet treatment supplemented with none (A: control/basal feed); $10 \mathrm{mg}$ avilamycin/ $\mathrm{kg}$ (B); $500 \mathrm{mg}$ eucalyptol/kg (C); $1000 \mathrm{mg}$ eucalyptol/kg (D); $500 \mathrm{mg}$ eugenol/kg (E); $1000 \mathrm{mg}$ eugenol/ $\mathrm{kg}(\mathrm{F}) ; 500$ $\mathrm{mg}$ eucalyptol $/ \mathrm{kg}$ plus $500 \mathrm{mg}$ eugenol/kg $(\mathrm{G})$. The essential oils in these diets were in microencapsulated form. The crumbled basal diets (Table 1) and water were provided ad lib from 1 to 21 days. We evaluated the performance of the chicks using the variables: initial weight, feed consumption (FC), weight gain (WG), food conversion (FC), mortality rate and final broiler weight. All the chicks were weighed at 1, 10 and 21 days of age.

The compounds avilamycin, halquinol, lincomycin, tiamulin, tylosin, ferulic acid, rutin, caffeic acid, chlorogenic acid, quercetin, and galic acid, BHA (butylated hydroxyanisole) and

Table 1 -Composition of the dietary feeds used in the experiments.

\begin{tabular}{|c|c|c|c|c|c|c|c|}
\hline \multirow{2}{*}{ Item $(\mathrm{g} / 100 \mathrm{~g})$} & \multicolumn{7}{|c|}{ Treatments $^{1}$} \\
\hline & $\mathrm{A}$ & B & $\mathrm{C}$ & $\mathrm{D}$ & $E$ & $\mathrm{~F}$ & $\mathrm{G}$ \\
\hline Corn & 52 & 52 & 52 & 52 & 52 & 52 & 52 \\
\hline Soy bran & 40.1 & 40.1 & 40.1 & 40.1 & 40.1 & 40.1 & 40.1 \\
\hline Soy oil & 3.52 & 3.52 & 3.52 & 3.52 & 3.52 & 3.52 & 3.52 \\
\hline Salt & 0.35 & 0.35 & 0.35 & 0.35 & 0.35 & 0.35 & 0.35 \\
\hline Limestone & 1.24 & 1.24 & 1.24 & 1.24 & 1.24 & 1.24 & 1.24 \\
\hline Dicalcium phosphate & 1.6 & 1.6 & 1.6 & 1.6 & 1.6 & 1.6 & 1.6 \\
\hline Methionine & 0.24 & 0.24 & 0.24 & 0.24 & 0.24 & 0.24 & 0.24 \\
\hline Premix ${ }^{2}$ & 0.3 & 0.3 & 0.3 & 0.3 & 0.3 & 0.3 & 0.3 \\
\hline Eucalyptol $^{3}$ & - & - & 0.245 & 0.49 & - & - & 0.245 \\
\hline Eugenol $^{3}$ & - & - & - & - & 0.245 & 0.49 & 0.245 \\
\hline Avilaycin & - & 0.001 & - & - & - & - & - \\
\hline Kaolin & 0.65 & 0.649 & 0.405 & 0.17 & 0.41 & 0.17 & 0.165 \\
\hline
\end{tabular}

${ }^{1}$ Treatments: A = control; B = Avilamycin $(10 \mathrm{mg} / \mathrm{kg}) ; \mathrm{C}=$ eucalyptol $(500 \mathrm{mg} / \mathrm{kg}) ; \mathrm{D}=$ eucalyptol $(1000 \mathrm{mg} / \mathrm{kg}) ; \mathrm{E}=$ eugenol $(500 \mathrm{mg} / \mathrm{kg}) ; \mathrm{F}=$ eugenol $(1000 \mathrm{mg} / \mathrm{kg}) ; \mathrm{G}=$ mixture of eugenol $(500 \mathrm{mg} / \mathrm{kg})$ and eucalyptol $(500 \mathrm{mg} / \mathrm{kg})$.

${ }^{2}$ Composition of premix (100 Kg): Vit. A: $1057500 \mathrm{IU}$, vit. D3: $255375 \mathrm{IU}$, vit. K: $180 \mathrm{mg}$, vit. B2: $450 \mathrm{mg}$, vit. B12: $1200 \mu \mathrm{g}$, vit. E: $787 \mathrm{mg}$, niacin: $3000 \mathrm{mg}$, pantothenic acid: $1173 \mathrm{mg}$, Vit B1: $201 \mathrm{mg}$, Vit B6: $249 \mathrm{mg}$, iron: $5589 \mathrm{mg}$, copper: $1101 \mathrm{mg}$, zinc: $5578 \mathrm{mg}$, manganese: $7203.6 \mathrm{mg}$, iodine: $84 \mathrm{mg}$, selenium: $43.5 \mathrm{mg}$, antioxidant (BHT): $378 \mathrm{mg}$. Calculated composition: Metabolizable energy (kcal/kg): 2950, Protein (\%): 22.5, Methionine (\%): 0.35, Methionine + cystine (\%): 0.71, Calcium (\%): 0.95, Available phosphorus (\%): 0.45.

${ }^{3}$ Microcapsules. 
DPPH (2,2-diphenyl-1-picryl-hydrazyl) were acquired from Sigma-Aldrich (St. Louis, MO, USA) or Absolute Standards, Inc (Hamden, CT, USA).

The purity of the fractions of eucalyptol and eugenol were determined as described by Scherer et al. (2010) on a gas chromatography coupled to flame ionization and mass spectrometry detectors (GC-17A-QP5000, Shimadzu, Japan). The antioxidant activity of the fractions was determined by DPPH (2,2diphenyl-1-picryl-hydrazyl) assay as described by Scherer and Godoy (2009). To determine the antimicrobial activity, we use the following microorganisms: Staphylococcus aureus (ATCC 6538), Escherichia coli (isolated from swine), Salmonella typhimurium (ATCC 14028), Pseudomonas aeruginosa (ATCC 13388) and Clostridium perfringens (ATCC 1324). The minimal inhibitory concentration (MIC) was determined in culture plates with 96 wells, according to the NCCLS (National Committee of Laboratory standards, 2003) norms. All the analyses were carried out in triplicate.

\section{Microencapsulation of Eucalyptol and Eugenol}

The microencapsulation of eucalyptol and eugenol was made using malt dextrin (20 DE), modified starch, the essential oils and water in the proportion of 1.5:1.0:1.5:3.5, respectively. The mixture was homogenized in a turrax and dried in a Lab Plant SD-05 double fluid (1.5 mm diameter) spray dryer (L.P. Technology, UK) at $180{ }^{\circ} \mathrm{C}$; air flow of $73 \mathrm{~m}^{3} \cdot \mathrm{h}^{-1}$, air inlet temperature: $180 \pm 2{ }^{\circ} \mathrm{C}$, air outlet temperature: $115 \pm 3{ }^{\circ} \mathrm{C}$ and flow rate: $0.7{\mathrm{~L} . \mathrm{h}^{-1}}^{-1}$.In order to assure the quality of the microcapsules, the amount of core material was determined by hydro-distillation in triplicate $5 \mathrm{~g}$ with $200 \mathrm{~mL}$ distilled water in a Clevenger system, being then analyzed by gas chromatography as described above.

\section{Statistical Analysis}

The statistical analyses were carried out using the software Statistic 6.0. The differences were considered significant with $\mathrm{P}<0.05$ (ANOVA/ Tukey's test).

\section{RESULTS AND DISCUSSION}

The fraction eugenol which was $99.90 \%$ pure according to the chromatographic analyses showed elevated in vitro antioxidant activity with an Antioxidant Activity Index (AAI) significantly $(\mathrm{P}<0.05)$ higher than those of rutin and ferulic acid, but lower $(\mathrm{P}<0.05)$ than those of gallic acid and quercetin (Table 2). The results found for eugenol fraction suggest that its use as substitute for antibiotics can promote additional benefits to the broilers. The AAI of eugenol revealed no significant difference to chlorogenic acid, caffeic acid and BHA. In contrast, eucalyptol which was $99.95 \%$ pure did not show DPPH-reducing capacity even at the highest concentration assessed $(0.8 \mathrm{mg} / \mathrm{mL})$.

In order to define the concentrations of eugenol and eucalyptol for the in vivo experiment, we investigated the antimicrobial activity of both fractions, comparing these results with those of the main antibiotics used as growth promoters. There was no difference in the antimicrobial activity between eucalyptol and eugenol for the microorganisms E. coli, $P$. aeruginosa and $S$. typhimurium. The antimicrobial action of essential oils on the intestinal flora can inhibit the growth of pathogens and consequently promote the development of benefic microorganisms which increase animal performance (BRENES and ROURA, 2010). $S$. aureus and $C$. perfringens were more sensitive to eugenol than to eucalyptol. Considering the classification of antimicrobial activity established by Duarte et al., (2005) both eucalyptol and eugenol showed from moderate to strong antimicrobial action. This result indicated a great potential for the eucalyptol and eugenol as substitutes for antibiotic growth promoters.

Considering the antimicrobial activity results (Table 3), for E. coli, the mean values for avilamycin, tilosin and halquinol were about 7 , 27 and 100 times lower, respectively, than the mean values of eucalyptol and eugenol. We compare the antimicrobial activity for 
Table 2- Results of antioxidant activity of the eucalyptol and eugenol compared to other chemicals antioxidantes.

\begin{tabular}{lcc}
\hline Compound & $\mathrm{IC}_{50}{ }^{1}$ & $\mathrm{AAI}^{2}$ \\
\hline Gallic acid & $2.83 \pm 0.07$ & $27.15 \pm 0.68^{\mathrm{a}}$ \\
Quercetin & $4.88 \pm 0.56$ & $15.92 \pm 1.76^{\mathrm{c}}$ \\
Eugenol & $6.99 \pm 0.32$ & $11.02 \pm 0.49^{\mathrm{d}}$ \\
Chlorogenic acid & $7.44 \pm 0.12$ & $10.34 \pm 0.17^{\mathrm{d}}$ \\
Caffeic acid & $8.21 \pm 0.31$ & $9.37 \pm 0.35^{\mathrm{d}}$ \\
BHA & $8.23 \pm 0.41$ & $9.36 \pm 0.46^{\mathrm{d}}$ \\
Rutin & $12.09 \pm 0.70$ & $6.38 \pm 0.37^{\mathrm{e}}$ \\
Ferulic acid & $14.45 \pm 0.66$ & $5.33 \pm 0.25^{\mathrm{e}}$ \\
Eucalyptol & $\mathrm{NA}$ & $\mathrm{NA}$ \\
\hline
\end{tabular}

${ }^{1}$ inhibitory concentration of $50 \%$ of the DPPH radicals $(\mu \mathrm{g} / \mathrm{mL})$

${ }^{2} \mathrm{AAI}=$ antioxidant activity index

${ }^{\mathrm{a}-\mathrm{e}}$ Means within a column with different superscripts differ $(\mathrm{P}<0.05)$. NA: no activity

Table 3- Minimal inhibitory concentration of eucalyptol and eugenol compared to avilaycin, halquinol, lincomycin, thiamulin and tylosin.

\begin{tabular}{lccccc}
\hline \multicolumn{5}{c}{ Minimal inhibitory concentration $(\mathbf{m g} / \mathbf{m L})$} \\
\hline Compound & S. aureus & E. coli & P. aeruginosa & S. typhimurium & C. perfringens \\
\hline Eucalyptol & 0.600 & 0.40 & 0.40 & 0.600 & 0.800 \\
Eugenol & 0.400 & 0.40 & 0.40 & 0.600 & 0.600 \\
Avilaycin & 0.004 & 0.06 & 0.06 & 0.060 & 0.060 \\
Halquinol & 0.004 & 0.004 & 0.03 & 0.015 & 0.015 \\
Lincomycin & $*$ & 0.03 & 0.03 & 0.030 & 0.030 \\
Thiamulin & $*$ & 0.03 & 0.06 & 0.060 & 0.060 \\
Tylosin & $*$ & 0.015 & 0.06 & 0.060 & 0.060 \\
\hline$* 0002 \mathrm{mg} / \mathrm{mL}$ & & \multicolumn{4}{c}{}
\end{tabular}

$*<0.002 \mathrm{mg} / \mathrm{mL}$

avilamycin with the eucalyptol and eugenol values. We find that 70 to $100 \mathrm{mg} / \mathrm{kg}$ of the compounds tested would be required for equivalence effect to the commercial antibiotic, considering that the frequently concentration of avilamycin used is $10 \mathrm{mg} / \mathrm{kg}$. It is known that are differences between in vitro and in vivo trials; therefore, the values for these fractions were super-estimate. We used concentrations of 500 and $1000 \mathrm{mg} / \mathrm{kg}$ for the eugenol and eucalyptol in the experiments with the broilers.

The chromatography analyses of the eucalyptol and eugenol in the microcapsules exhibited values of $20.4 \pm 0.2 \mathrm{~g} / 100 \mathrm{~g}$ and $20.8 \pm 0.9$ $\mathrm{g} / 100 \mathrm{~g}$, respectively. Consequently, there were losses of both eucalyptol and eugenol during the spray-drying process, probably due to the volatility of the compounds. The hydrodistilled fraction extracted from the microcapsules was analyzed by gas chromatography and the results revealed no significant alteration, with values for purity of 99.5 and $99.1 \%$ for eucalyptol and eugenol, respectively.
Only three deaths occurred during the experiment, one with the treatment with 1000 $\mathrm{mg} / \mathrm{kg}$ eugenol and one with $1000 \mathrm{mg} / \mathrm{kg}$ eucalyptol, both at 7 days of age, and one after 19 days of treatment with $500 \mathrm{mg} / \mathrm{kg}$ eugenol. There was no significant difference in the initial weights of the broilers between any of the treatments (Table 4). Treatment G $(500 \mathrm{mg} / \mathrm{kg}$ eucalyptol and $500 \mathrm{mg} / \mathrm{kg}$ eugenol) showed the lowest feed consumption, smallest weight gain, lowest food conversion and lowest weight after 21 days $(\mathrm{P}<0.05)$. The mixture of the two compounds may have contributed to the formation of an unpleasant odor in the diet, since the birds in this group had significantly lower feed intake. In contrast, the treatments with 10 $\mathrm{mg} / \mathrm{kg}$ of avilamycin, $500 \mathrm{mg} / \mathrm{kg}$ of eucalyptol, $500 \mathrm{mg} / \mathrm{kg}$ of eugenol and $1000 \mathrm{mg} / \mathrm{kg}$ of eucalyptol showed the best food conversion indexes (Table 4).

In the period from 1 to 21 days of growth, no significant differences were detected in the feed consumption, weight gain and final weight between the broilers in the control group, 10 $\mathrm{mg} / \mathrm{kg}$ avilamycin, $500 \mathrm{mg} / \mathrm{kg}$ eucalyptol and 
Table 4- Effects of different dietary treatments on broilers performance.

\begin{tabular}{|c|c|c|c|c|c|}
\hline Treatment $^{1}$ & $\begin{array}{c}\text { Initial } \\
\text { weight (g) }\end{array}$ & $\begin{array}{c}\text { Feed } \\
\text { consumption (g) }\end{array}$ & $\begin{array}{l}\text { Weight } \\
\text { gain }(g)\end{array}$ & $\begin{array}{c}\text { Food } \\
\text { conversion }(\mathrm{g} / \mathrm{g})\end{array}$ & $\begin{array}{c}\text { Final } \\
\text { weight (g) }\end{array}$ \\
\hline \multicolumn{6}{|c|}{1 to 10 days } \\
\hline$A$ & $45 \pm 1^{\mathrm{a}}$ & $228 \pm 4^{\mathrm{a}}$ & $198 \pm 4^{\mathrm{ab}}$ & $1.18 \pm 0.05^{\mathrm{b}}$ & $243 \pm 4^{\mathrm{a}}$ \\
\hline $\mathrm{B}$ & $45 \pm 1^{\mathrm{a}}$ & $233 \pm 9^{a}$ & $206 \pm 8^{a}$ & $1.10 \pm 0.03^{\mathrm{bc}}$ & $252 \pm 8^{a}$ \\
\hline $\mathrm{C}$ & $45 \pm 1^{\mathrm{a}}$ & $224 \pm 9^{a}$ & $205 \pm 7^{\mathrm{a}}$ & $1.08 \pm 0.09^{\mathrm{bc}}$ & $251 \pm 8^{a}$ \\
\hline $\mathrm{D}$ & $45 \pm 1^{\mathrm{a}}$ & $222 \pm 12^{\mathrm{a}}$ & $201 \pm 9^{a}$ & $1.12 \pm 0.08^{\mathrm{bc}}$ & $246 \pm 9^{a}$ \\
\hline $\mathrm{E}$ & $45 \pm 2^{\mathrm{a}}$ & $229 \pm 7^{\mathrm{a}}$ & $201 \pm 8^{a}$ & $0.99 \pm 0.08^{c}$ & $246 \pm 8^{a}$ \\
\hline $\mathrm{F}$ & $45 \pm 1^{\mathrm{a}}$ & $222 \pm 9^{a}$ & $186 \pm 3^{\mathrm{ab}}$ & $1.19 \pm 0.05^{\mathrm{b}}$ & $232 \pm 5^{b}$ \\
\hline $\mathrm{G}$ & $44 \pm 1^{\mathrm{a}}$ & $200 \pm 13^{b}$ & $142 \pm 11^{\mathrm{c}}$ & $1.6 \pm 0.14^{\mathrm{a}}$ & $187 \pm 11^{\mathrm{c}}$ \\
\hline \multicolumn{6}{|c|}{1 to 21 days } \\
\hline$A$ & $45 \pm 1^{\mathrm{a}}$ & $1164 \pm 38^{a b}$ & $985 \pm 30^{\mathrm{b}}$ & $1.18 \pm 0.02^{\mathrm{c}}$ & $1031 \pm 31 b^{c}$ \\
\hline $\mathrm{B}$ & $45 \pm 1^{\mathrm{a}}$ & $1161 \pm 30^{\mathrm{ab}}$ & $1001 \pm 18^{\mathrm{ab}}$ & $1.16 \pm 0.01^{\mathrm{cd}}$ & $1046 \pm 19^{\mathrm{ab}}$ \\
\hline $\mathrm{C}$ & $45 \pm 1^{\mathrm{a}}$ & $1146 \pm 21^{\mathrm{b}}$ & $1014 \pm 12^{\mathrm{ab}}$ & $1.13 \pm 0.02^{\mathrm{d}}$ & $1060 \pm 12^{\mathrm{ab}}$ \\
\hline $\mathrm{D}$ & $45 \pm 1^{\mathrm{a}}$ & $1170 \pm 37^{\mathrm{ab}}$ & $1020 \pm 25^{\mathrm{ab}}$ & $1.15 \pm 0.02^{\mathrm{d}}$ & $1066 \pm 25^{\mathrm{ab}}$ \\
\hline $\mathrm{E}$ & $45 \pm 2^{\mathrm{a}}$ & $1221 \pm 55^{\mathrm{a}}$ & $1039 \pm 40^{\mathrm{a}}$ & $1.17 \pm 0.01^{\mathrm{c}}$ & $1085 \pm 41^{\mathrm{a}}$ \\
\hline $\mathrm{F}$ & $45 \pm 1^{\mathrm{a}}$ & $1182 \pm 25^{\mathrm{ab}}$ & $971 \pm 22^{b}$ & $1.22 \pm 0.02^{\mathrm{b}}$ & $1016 \pm 22^{c}$ \\
\hline $\mathrm{G}$ & $44 \pm 1^{\mathrm{a}}$ & $977 \pm 81^{\mathrm{c}}$ & $721 \pm 64^{c}$ & $1.36 \pm 0.03^{\mathrm{a}}$ & $766 \pm 65^{d}$ \\
\hline
\end{tabular}

$1000 \mathrm{mg} / \mathrm{kg}$ eucalyptol groups (Table 4). Botsoglou et al., 2002 tested the addition of two levels of essential oil from oregano to the diet of broilers (50 and $100 \mathrm{mg} / \mathrm{kg}$ ), however no performance improvement was observed when compared with the control group. On the other hand, Mathlouthi et al. (2011) assessed the effects of essential oils of rosemary, oregano and a commercial blend of essential oils in broiler chickens diet, and the results exhibited that the three essential oils tested can substitute growth promoter antibiotics.

Zakeri and Kashefi (2011) studied effects of avilamycin, protexin, nutracid focus, mannanoligosaccharides and vitacel in broiler chicken feed on humoral immunity, growth performance, mortality and feed intake. The birds fed with mannanoligosaccharides and protexin had superior $(\mathrm{P}<0.05)$ serum antibodies at the age of 25 days old. Falaki et al., (2011) assessed the effects of different levels of probiotic and prebiotic on growth performance and carcass characteristics of broiler chickens. The highest value of body weight gain, carcass and breast was verified for broilers fed with mixed of probiotic $(900 \mathrm{mg} / \mathrm{kg})$ and prebiotic (2000 mg/kg) supplementation. The authors related that supplemented diets with mixed of probiotic and prebiotic (symbiotic) as growth promoters improve broiler chickens growth indices.

The treatments C (500 mg/kg eucalyptol) and E (500 $\mathrm{mg} / \mathrm{kg}$ eugenol) showed no difference $(\mathrm{P}<0.05)$ with the $10 \mathrm{mg} / \mathrm{kg}$ avilamycin treatment in the tested conditions. The treatments $\mathrm{C}$ and $\mathrm{E}$ presented better $(\mathrm{P}<0.05)$ food conversion and weight gain, respectively, as compared to the control (Table 4).

\section{CONCLUSIONS}

The eugenol demonstrated strong antioxidant activity and both eugenol and eucalyptol showed antimicrobial activity. The broiler performance showed no significant difference to the group with administration of $10 \mathrm{mg} / \mathrm{kg}$ of avilamycin when eucalyptol $(500 \mathrm{mg} / \mathrm{kg})$ or eugenol $(500 \mathrm{mg} / \mathrm{kg})$ were used separately in diet. Our findings strongly suggest that the use of microencapsulated eucalyptol and eugenol in the tested conditions could be considered as effective alternatives for the commercial antibiotics growth promoters in broilers during the growing phase. 


\section{REFERENCES}

AGUILAR, C. A. L.; LIMA, K. R. S.; MANNO, M. C.; TAVARES, F. B.; SOUZA, V. S.; NETO, D. L. F. Effect of copaiba essential oil on broiler chickens' performance. Acta Scientiarum, v. 35, n. 2, p. 145-151, 2013.

BOTSOGLOU, N. A; FLOROU-PANERI, P.; CHRISTAKI, E.; FLETOURIS, D. J.; SPAIS, A. B. Effect of dietary oregano essential oil on performance of chickens and on iron-induced lipid oxidation of breast, thigh and abdominal fat tissues. British Poultry Science, v.43, n. 2, p. 223-230, 2002. DOI: $10.1080 / 00071660120121436$.

BRENES, A \& ROURA, E. Essential oils in poultry nutrition: Main effects and modes of action. Animal Feed Science and Technology, V. 158, n. $1-2$, p. $1-14,2010$. DOI: 10.1016/j.anifeedsci.2010.03.007.

CASEWELL, M.; FRIIS, C.; MARCO, E.; MC MULLIN, P.; PHILLIPS, I. The European ban on growth-promoting antibiotics and emerging consequences for human and animal health. Journal of Antimicrobial Chemotherapy, v. 52, n. 2 , p. 159-161, 2003. DOI: $10.1093 / \mathrm{jac} / \mathrm{dkg} 313$.

CASTANON, J. I. History of the use of antibiotic as growth promoters in European poultry feeds. Poultry Science, v. 86, n.11, p. 2466-2471, 2007. DOI: 10.3382/ps.200700249.

CROSS, D. E.; MC DEVITT, R. M.; HILLMAN, K.; ACAMOVIC, T. The effects of herbs and their associated essential oils on performance, dietary digestibility and gut microflora in chickens from 7 to 28 days of age. British Poultry Science, v. 48, n. 4, p. 496-506, 2007. DOI: $10.1080 / 00071660701463221$.

DUARTE, M. C.; FIGUEIRA, G. M.; SARTORATTO, A.; REHDER, V. L.; DELARMELINA, C. Anti-Candida activity of Brazilian medicinal plants. Journal of Ethnopharmacology, v. 97, n. 2, p. 305-31, 2005.

FALAKI, M.; SHAMS SHARGH, M.; DASTAR, B.; ZEREHDARAN, S. Effects of different levels of probiotic and prebiotic on performance and carcass characteristics of broiler chickens. Journal of Animal and Veterinary Advances, v. 10, n. 3, p. 378-384, 2011. DOI: 10.3923/javaa.2011.378.384.

FARAG, R. S.; BADEI AZ, HEWEDI FM, ELBAROTY GS: Antioxidant activity of some spice essential oils on linoleic acid oxidation in aqueous media. Journal of the American Oil Chemists Society, v. 66, n. 6, p. 792-799, 1989. DOI:10.1007/BF02653670.

HELANDER, I. M.; ALAKOMI, H. L.; LATVA-KALA, K.; MATTILA-SANDHOLM, T.; POL, I.; SMID, E. J.; GORRIS, L. G. M.; VON WRIGHT, A. Characterization of the action of selected essential oil components on Gram-negative bacteria. Journal of Agricultural and Food Chemistry, 1998, v. 46, n. 9, p. 35903595, 1998. DOI: 10.1021/jf980154m.

JAMROZ, D.; WERTELECKI, T.; HOUSZKA, M.; KAMEL, C. Influence of diet type on the inclusion of plant origin active substances on morphological and histochemical characteristics of the stomach and jejunum walls in chicken. Journal of Animal Physiology and Animal Nutrition, v. 90, n.5-6, p. 255-268, 2006.

JANG, I. S.; KO, H. Y.; HA, J. S.; KIM, J. Y.; KANG, S. Y.; YOO, D. H.; NAM, D. S.; KIM, D. H.; LEE, C. Y. Influence of essential oil components on growth performance and the functional activity of the pancreas and small intestine in broiler chickens. Asian-australasian Journal of Animal Sciences, v. 17, n. 3, p. 394400, 2004.

KHAKSAR, V.; VAN KRIMPEN, M.; HASHEMIPOUR, H.; PILEVAR, M. Effects of Thyme Essential Oil on Performance, Some Blood Parameters and Ileal Microflora of Japanese Quail. The Journal of Poultry Science, v. 49, n. 2, p. 106-110, 2012.

KHODAMBAS, H. I.; EMAMIEMAIL, N.; SAMIE, A.; RAHMANI, H. R.; RUIZ-FERIA, C. A. The effect of peppermint essential oil and fructooligosaccharides, as alternatives to virginiamycin, on growth performance, digestibility, gut morphology and immune response of male broilers. Animal Feed Science and Technology, v. 175, n. 1-2, p. 57-64, 2012.

LEE, H. S.; AHN, Y. J. Growing-inhibiting effects of cinnamomun cassia bark-derived 
materials on human intestinal bacteria. Journal of Agricultural and Food Chemistry, v.19, n. 46, p. 8-12, 1998.

LEE, K. W.; EVERTS, H.; KAPPERT, H. J.; FREHNER, M.; LOSA, R.; BEYNEN, A. C. Effects of dietary essential oil components on growth performance, digestive enzymes and lipid metabolism in female broiler chickens. British Poultry Science, v. 44, n. 3, 2003.

MATHLOUTHI, N.; BOUZAIENNE, T.; OUESLATI, I.; RECOQUILLAY, F.; HAMDI, M.; URDACI, M.; BERGAOUI, R. Use of rosemary, oregano, and commercial blend of essential oils in broiler chickens: in vitro antimicrobial activities and effects on growth performance. Journal of Animal Science, v. 90, n. 3, p. $813-23$, 2012. DOI: $10.2527 /$ jas.20103646.

MARTINS, M. I.; BARREIRO, M. F.; COELHO, M.; RODRIGUES, A. E. Microencapsulation of essential oils with biodegradable polymeric carriers for cosmetic applications. Chemical Engineering Journal, 245, 191-200, 2014. http://dx.doi.org/10.1016/j.cej.2014.02.024

National Committee of Laboratory standards. Methods for Dilution Antimicrobial Susceptibility Tests for Bacteria That Grow Aerobically. Approved Standard, edition $\mathrm{n}^{\circ} 6$. NCCLS document M7-A6 (ISBN 1-56238-4864). Pennsylvania, USA, 2003.

PHILLIPS, I.; CASEWELL, M.; COX, T.; DE GROOT, B.; FRIIS, C.; JONES, R.; NIGHTINGALE, C.; PRESTON, R; WADDELL, J. Does the use of antibiotics in food animals pose a risk to human health? A critical review of published data. Journal of Antimicrobial Chemotherapy, v. 53, n. 1, p. 2852, 2004. DOI: $10.1093 / \mathrm{jac} / \mathrm{dkg} 483$.

ROSEN, G. D. Pronutrient antibiotic replacement standards discussed. Feedstuffs, v. 75, p. 11-13, 1996.

MYINT, S.; DAUD, W. R.; MOHAMAD, A. B.; KADHUM, A. A. Gas chromatographic determination of eugenol in ethanol extract of cloves. Journal of Chromatography B, v. 679, n. 1-2, p. 193-195, 1996.
SCHERER, R.; GODOY, H. T. Antioxidant activity index (AAI) by 2,2-diphenyl-1picrylhydrazyl method. Food Chemistry, v. 112, n. 3, p. 654-658, 2009.

SCHERER, R.; WAGNER, R.; MEIRELES, M. A.; GODOY, H. T. Biological Activity and Chemical Composition of Hydrodistilled and Supercritical Extracts of Xanthium strumarium leaves. Journal of Essential Oil Research, v. 22, n. 5, p. 424-429 2010.

VAREL, V. H. Livestock manure odor abatement with plant-derived oils and nitrogen conservation with urease inhibitors: a review. Journal of Animal Science, v. 80, n.2, p. E1-E7, 2002.

WINDISCH, W.; SCHEDLE, K.; PLITZNER, C.; KROISMAYR, A. Use of phytogenic products as feed additives for swine and poultry. Journal of Animal Science, v. 86, n. 14, p. E140-E148, 2008. DOI: 10.2527/jas.20070459.

ZAKERI, A.; KASHEFI, P. The comparative effects of five growth promoters on broiler chickens humoral immunity and performance. Journal of Animal and Veterinary Advances, v. 10, n. 9, p. 1097-1101, 2011. DOI: 10.3923/javaa.2011.1097.1101. 